\title{
Law Enforcement of Waste Management in An Effort to Reduce Flood Risk in Indonesia
}

\author{
Azhar $^{\star}$; Kgs M. Sobri ${ }^{\star \star}$; Abdul Halim ${ }^{\star \star \star}$ \\ ^International Relations Department, Faculty of Social and \\ Political Sciences, Sriwijaya University-Indonesia. \\ azhar@fisip.unsri.ac.id \\ ${ }^{\star \star}$ Public Administration Department, Faculty of Social and \\ Political Sciences, Sriwijaya University-Indonesia. \\ kmsobri@gmail.com \\ $\star \star \star$ International Relations Department, Faculty of Social and \\ Political Sciences, Sriwijaya University-Indonesia. \\ abdul.halim@fisip.unsri.ac.id
}

\begin{abstract}
The aim of this paper is to identify law enforcement of waste management and formulate a law enforcement model for urban waste management in an effort to reduce flood risk. The explanatory survey was used in this study. Quantitative and qualitative approaches were used to explain the relationship between several variables. Sampling techniques were carried out in stages, and proportionally according to the research objectives. Besides, the data collection in this study carried out through observation, in-depth interviews, documentation and audio visual. The data analysis technique used descriptive qualitative through an interactive model developed by Miles and Huberman consisting of four interacting components, namely data collection, data reduction, data presentation and drawing conclusions and verification. Results indicate that there are some issues in law enforcement of waste management. First, the total number of law enforcers is not enough. Second, there are lack of facilities and infrastructures such as garbage cans, collection, temporary landfills, transportation and final
\end{abstract}


processing. Third, there is a lack of commitment by the authorities in enforcing waste management laws related to reducing the risk of flooding. Furthermore, public awareness to comply with waste management is very law. Finally, there is still a lack of public awareness of the risk of flood. In conclusion, almost half of the community is aware that disposing of garbage in its place is very important for their survival and flood risk in their area. On the other hand, half of the people who do not care and still throw waste not properly.

Keywords: law enforcement; waste management; flood risk; urban.

\section{A. Introduction}

Indonesia as a state of law ${ }^{1}$ constitute a constitutional basis. The law is placed as the only rule in the life of society, nation and state or known as the supremacy of law. After the amendment of the 1945 Constitution, environmental law enforcement is placed in articles relating to human rights. One of the articles is article $28 \mathrm{H}$ paragraph 1 of the 1945 Law, which states:

"Everyone has the right to live in physical and spiritual prosperity, to live, and to have a good and healthy living environment and to have the right to health services."

The above article is a strong foundation that the environment must be important in the context of protecting human rights in Indonesia. Thus, environmental law enforcement becomes an important element in the protection of human rights. Enforcement of environmental law in the community must be able and empowered to adapt to offset changes in the development process, which includes economic, social, cultural and ecological/environmental aspects. ${ }^{2} \mathrm{One}$ of the development impacts related to ecological aspects is flooding.

Flood is a condition where an area or land is submerged due to increased water volume. ${ }^{3}$ In recent decades, flooding has increased

1 This is stated in Article 1 paragraph (3) of the 1945 Constitution. The 4 th Amendment states that: "Indonesia is a state of law".

2 A. Boyle, "Human Rights and the Environment: Where Next?", European Journal of International Law, 23 (3), 2012, p. 624.

3 Law of the No. 24/2017 on Disaster Countermeasure. 
globally. ${ }^{45}$ As a result, an increase in flooding also impacts the risks that must be accepted by the community in terms of physical, social, and economic, such as the destruction of infrastructure, obstruction economic activity, loss of livelihood, and loss of life a little. ${ }^{6}$ The International Federation of Red Cross records among species other natural disasters, floods are disasters that cause losses and the most severe damage. ${ }^{7}$ Floods had an immediate impact on an average of 99 million lives per year worldwide from 2000 to 2008. In fact, noted that there were 178 million people directly affected by the floods in 2010. The total loss caused by floods from 1998 to 2008 reached US $\$ 40$ trillion. $^{8}$

As a center of social and economic growth from the local to the global level, urban area is one of the regions on the surface of the earth that is vulnerable to floods. ${ }^{9}$ This is caused by social and economic activities of the community, such as rapid population growth, economic activity growth, degradation the environment, and the process of urbanization in urban areas that are not supported by adequate urban planning and management. ${ }^{10}$

Palembang is one of the big cities in Indonesia which is densely populated. Palembang still holds the highest number in the problem

4 IFRC, World Disaster Report 2010: Focus On Urban Risk, Geneva: IFRC, 2010.

5 B. AJha,\&J, Lamond. (2012). Cities and flooding: a guide to integrated urban flood risk management for the 21st century. W. World Bank Publications.

6 C.J., Bradshaw, N.S., Sodhi, PEH, K.S.H., \& B.W, Brook., "Global evidence thatdeforestation amplifies flood risk and severity in the developing world", Global Change Biology, 13(11), 2007, p. 2388.

7 IFRC, 2010.

8 B. A., Jha, \& J, Lamond, 2012.

9 R. J., Nicholls, "Coastal Flooding and Wetland Loss in the 21st Century: Changes under the SRES Climate and Socio-Economic Scenarios”, Global Environmental Change, 14(1), 2004, p. 72.

10 I. Adeleka, "Vulnerability assessment of an urban flood in Nigeria: Abeokuta flood 2007”, Natural Hazards 56 (1), 2011, p. 220; J. Birkmann, M. Garschagen, F. Krass, \& N. Quang, "Adaptive urban governance: new challenges for the second generation of urban adaptation strategies to climate change”, Sustainability Science, 5(2), 2010, p. 188; B. Razafindarabe, R. Kada, M. Arima, \& S. Inous, "Analyzing Flood Risk and Related Impacts to Urban Communities in Central Vietnam", Mitigation and Adaptation Strategies for Global Chang, 2012 , p. 10. 
of flooding. In 2019 floods occurred in 51 places and repeatedly occurred in the same place. ${ }^{11}$ In Palembang, flood-prone areas such as areas are found, Jenderal Sudirman street in front of the Sintera Hotel, Basuki Rahmat street Polda area, R Sukamto street in front of Pindang Meranjat RM, Demang Lebar Daun street between Angkatan 45 street and Siti Khodijah Hospital and Middle Sekip (road Major Salim Batubara) and Captain Arivai road especially in front of Palembang Icon and the Governor's Office.

This research will focus on looking at one of the causes of flooding, which is waste or garbage. Waste problem is a big problem faced by the community urban settlements. The development of Palembang City was marked by the increasing number of residents living in residential areas of Palembang city. The increase in population has implications for volume waste produced by the community. Along with the development of the City Palembang, development growth also increased and had an impact solid and liquid waste volume growth.

Waste is leftover material that is not expected after it ends a process. Waste is a man-made concept, in natural processes there is no rubbish that only products do not move. ${ }^{12}$ Population growth, changes in consumption patterns, and lifestyle the community has increased the number of landfills, types and diversity garbage characteristics. ${ }^{13}$ Increased purchasing power of the people towards various types staples and technology products as well as business or supporting activities The economic growth of a region also contributes greatly to the amount and quality of waste produced. Increased heap volume waste management needs. Waste management that does not

11 Walhi, Catatan Akhir Tahun 2019 : Tinjauan Lingkungan Hidup Sumatera Selatan, 2019. Retrieved Mei 2020, from www.walhi.or.id: https: / /www.walhi. or.id/wp-content/ uploads / Laporan\%20Tahunan/ catahu.pdf.

12 S.M, Elgizawy, El-Haggar, \&K, Nassar, "Approaching sustainability of construction and demolition waste using zero waste concept", Low carbon economy, 7(1), 2016, p. 5.

13 J.P. Holdren,\&, P.R. Ehrlich, "Human Population and the Global Environment: Population growth, rising per capita material consumption, and disruptive technologies have made civilization a global ecological force”, American scientist, 62(3), 1974, p. 288. 
use waste management methods and techniques that are environmentally friendly will be able to negative impact on health will also greatly affect environmental sustainability, environment, forests, rice fields, rivers, drainage and the ocean. ${ }^{14}$ This paper will try to discuss about law enforcement of waste management in an efforts to reduce floods in Indonesia with a case study in Palembang city.

\section{B. Literature Review}

This article will use some of the literature that is used as a basis for thinking in this paper. This literature review will be grouped into three major groups covering literature that talks about conceptual law enforcement, waste management conditions and problems that occur in Indonesia, especially the city of Palembang and previous research studies that talk about law enforcement in the environmental sector that have been carried out.

Law enforcers are those who enforce the law, in a sense narrow only means the police, prosecutors who then expanded to include it as well judges, lawyers, Civil Service Police Unit and correctional institutions. According to Black law dictionary means the act of putting something like a law into effect, the execution of a law. Whereas the law enforcement officer means those whose duty it is to preserve the peace. ${ }^{15}$

Law enforcement basically fulfills several elements, among others can provide benefits or be effective (utility), achieve some justice, and legal certainty. This means that in principle law enforcement must be able provide benefits or efficient (utility) for the community, in addition the community also expects that law enforcement can be achieved justice. Nevertheless that which is considered useful (sociologically) not necessarily fair, and vice versa which feels fair (philosophically), not yet certainly useful for the community. Under such conditions, society only want a certainty of law, in other words

14 B.R. Scanlon, I. Jolly, M. Sophocleous, \& L. Zhang, "Global Impact of Conversions from Natural to Agricultural Ecosystems on Water Resources: Quantity versus Quality”, Water Resources Research, 43 (3), 2007.

15 B. A, Garner, Black Law Dictionary, St. Paul: West Publishing, 1999. 
the existence of a regulation that can fill the legal vacuum without regard to whether the law is fair or not. ${ }^{16}$

Law enforcement is the process of implementing efforts to uphold or the actual functioning of legal norms as a guideline for perpetrators in the past cross or legal relations in community and state life. Besides that law enforcement is an effort to realize ideas and concepts the concept of law that is expected by the people to come true. Law enforcement is a process that involves many things. ${ }^{17}$ Then, Soerjono Soekanto said that law enforcement is the activity of harmonizing the relationships of values that are spelled out in the rules / views of steady values and manifesting them in the attitude of action as a series of translation of the final stages of value for creating, maintaining and maintain peace of association of life. ${ }^{18}$ Concrete law enforcement is positive internal law enforcement practice as it should be obeyed. Therefore, it provides justice in a case means to decide the law in concreto in defense and guaranteeing compliance with material laws using procedures that are determined by formal law. ${ }^{19}$

According to Satjipto Raharjo, law enforcement on essentially is the establishment of ideas or concepts about justice, truth, social benefit, and so on. ${ }^{20}$ So, law enforcement is efforts to realize ideas and concepts to become reality. In essence law enforcement to realize the values or methods which contains justice and truth. Law enforcement is not only a duty from law enforcers who are already conventionally known, but also become the duty of everyone. Even so, in relation to the law public, then the government is responsible. ${ }^{21}$

Furthermore, law enforcement is also a series of elaboration processes legal ideas and ideals that contain moral values such as jus-

16 Jambi, R., Teori Penegakan Hukum yang Menjamin Kepastian Hukum, 2015.

17 S. Dellyana, Konsep Penegakan Hukum (the Concept of Legal Enforcement) . Yogyakarta: Liberty, 1998.

18 S. Soekanto, Faktor-faktor yang Mempengaruhi Penegakan Hukum (Factors Affecting Law Enforcement), Jakarta: Raja Grafindo Persada, 2004.

19 S. Dellyana. Ibid.

20 S. Rahardjo, Penegakan Hukum: Suatu Tinjauan Sosiologis (Law Enforcement: A Sociological View), Yogyakarta: Genta Publishing, 2009.

21 Ibid. 
tice and truth into concrete forms, in realizing it requires an organization such as the police, prosecutors, courts and correctional institutions as elements classical law enforcement formed by the state, in other words that law enforcement in essence contains the supremacy of substantial values of justice. ${ }^{22}$

Soejono Soekanto elaborates on several Factors affecting law enforcement are as follows:

1. The legal factor itself is the legislation.

2. Law enforcement factors, namely those who form and apply the law.

3. Factors of facilities or facilities that support law enforcement.

4. Community factors, namely the environment in which the law applies or is applied.

5. Cultural factors, namely as the results of works, inventions, and tastes based on human initiative in the association of life. ${ }^{23}$

First the legal factor. The Implementation law in the field there are times when there is a conflict between legal certainty and justice, this is caused by the conception of justice which is a formula abstract, while legal certainty is a procedure that has been determined normatively. ${ }^{24} \mathrm{~A}$ policy or action that is not entirely based on law is something that can be justified as long as the policy or action is not contrary to law. So in essence the administration of law is not only covers law enforcement, but also but also peace maintenance, because the implementation of law is actually a process of harmonizing values methods and real behavioral patterns aimed at achieving peace. In practice we see there are most statutory regulations obeyed and there are also laws and regulations which are not obeyed. Legal system clearly collapse if everyone does not obey the laws and regulations the laws and regulations lose their meaning. Ineffectiveness of regulations legislation tends to influence the attitude time and quantity of non-compliance and has a real effect on legal behavior, including the behavior of violators law. This condition affects law

22 Ibid.

23 S. Soekanto, Op. Cit.

24 Ibid. 
enforcement which guarantees certainty and justice in society.

Second, the factor of law enforcement officers is the parties who form and apply the law which includes motivation, competence of law enforcement officers, the mentality or personality of law enforcement officers plays a very important role very important. ${ }^{25} \mathrm{Al}-$ though the existing regulations are already good, if the enforcement apparatus the law does not have competence in the field of duty, does not have good motivation and mentality or corrupt and unsafe personality and not honestly, it is not possible to enforce the law as expected. By Therefore, one of the keys to success in law enforcement is competence, motivation, mentality and or personality of the law enforcement officer concerned. Besides the number or ratio of law enforcers is not enough.

Third, the factor of supporting facilities or law enforcement facilities. Facility factor or supporting facilities include softskills and hardskills. Kind examples of softskills are science, education and competence in their field. ${ }^{26}$ Education and training received by the authorities law enforcement today tends to conventional practical matters. So that in many cases law enforcement officers experience obstacles inside assignment. Among them is knowledge of environmental governance knowledge,Cyber crimes, in particular criminal offenses which have so far been given authority to the public prosecutor. That is because it is technically juridical law enforcement officials are considered not yet capable and not ready. Although realized also that the tasks that must be carried out by lawenforcement officers are so broad and numerous. While hardware includes buildings, equipment, operational costs and inadequate salary.

The fourth factor is the community factor where law enforcement officials come from from the community and aims to achieve peace in the community and the environment in which the law applies or applies to every citizen of the community or groups more or less have legal awareness, problems that arise is the level of legal 
compliance, i.e. high, medium, or legal compliance less. ${ }^{27}$ The degree of community legal compliance with the law in the environment where the law applies or is applied, is one indicator the functioning of the law.

Finally, cultural factors are the result of creation, creation, and taste based on human initiative in the association of life. ${ }^{28}$ Based on the concept everyday culture, people often talk about culture. Culture according to Soerjono Soekanto, has a very large function for humans and society, that is regulating so that humans can understand how should act, act and determine their attitude if they are related with other people. Thus, culture is a main line about the behavior that sets the rules.

The second group of literature will talk about the risk of flooding that occurs in several areas, especially the city of Palembang. Kodoatie and Syarief explain the factors that cause floods include waste disposal, land use change, erosion and sedimentation, slums along rivers, improper flood control systems, high rainfall, river physiography, inadequate river capacity, influence high tide, land subsidence, water structures, damage to flood control buildings, blocked drainage by garbage, garbage disposal in creeks and rivers. ${ }^{29}$ In different studies, the factors that cause floods include rainfall intensity, inadequate drainage capacity, tidal river water, increasing population, silting of rivers due to people throwing garbage into the river. ${ }^{30}$

The risk of flooding cannot be separated from the consumptive condition of the community and the increasingly dense population of the easy movement of people from one area to another. This phenomenon of displacement is known as urban. And big cities

27 Ibid.

28 Ibid.

29 R. J., Kodoatie, \& R., Sjarief, Pengolahan Bencana Terpadu (Integrated Disaster Management), Jakarta: Yarsif Watampone, 2006.

$30 \mathrm{M}$, Belladona, Analisis faktor lingkungan penyebab banjir Kota Palembang (Analysis on the Environmental Factors Causing Flooding in Palembang City), 2005. Retrieved Mei 2020, from www.etd.repository.ugm.ac.id: http://etd.repository.ugm.ac.id/ home/detail_pencarian/26680. 
are one of the destinations for moving people. In an article entitled "Urban flood disaster management, it is stated that flooding is a phenomenon that often occurs in urban areas. Managerial of the flood problem needs to be made a careful planning. This paper offers a management concept in handling this problem by looking at the risk of flooding that occurs, making backfilling plans, implementing and evaluating to effectively solve existing problems. ${ }^{31}$

The third group of literature used will discuss about law enforcement in environmental issues. In a journal article entitled Law Enforcement of Electrical and Electronic Waste Smuggling in Batam, Indonesia written by FX. Joko Priyono in the journal Diponegoro Law Review which talks about law enforcement related to electronic waste processing in the city of Batam, Indonesia. In the findings of the research conducted, electronic waste in Batam comes from both inside and outside Batam. Waste originating from within the city of Batam is electronic waste from massive industries in Batam City, while other electronic waste comes from shipping waste from neighboring countries such as Singapore, Malaysia, Thailand and Vietnam. This shipping of waste from neighboring countries is a form of illegal smuggling of waste. Law enforcers actually know about the smuggling of electronic waste from these countries, but weak law enforcement is a factor in the ease of smuggling of electronic waste. The lack of understanding of law enforcers regarding electronic waste sent from neighboring countries and the economic value obtained by local residents are the two main factors that cause burnt electronic waste to be a problem that is often overlooked. ${ }^{32}$

The next literature entitled Law and Policy in addressing marine Plastic litter: Indonesia Response and Recent Development journal articles written by Maruf in the Journal of Indonesian Legal Studies focuses on the discussion of the sea as the future of a nation that can contribute a lot to Indonesian citizens. The condition of the sea,

31 T., Tingsanchali, "Urban Flood Disaster Managements", Procedia Engineering, 2012, p. 27.

32 F. J. Priyono, "Law Enforcement of Electrical and Electronic waste smuggling in Batam, Indonesia”, Diponegoro Law Review, 2017. 
which contains so much plastic waste, is a big problem in creating a vision for the future of Indonesia which is based on the sea. This research emphasizes on the importance of laws and policies owned by Indonesia in responding and giving special attention to the condition of plastic waste in order to create the sea as the future of the nation for all Indonesian people. This research focuses on the presidential regulation which emphasizes improvements in the marine sector and the problem of plastic waste in the sea. Presidential regulations were issued twice to improve existing conditions. ${ }^{33}$

\section{Research Method: Questionnaires}

This study used a questionnaire as an instrument for obtaining data. The questionnaire consisted of two sections:

Part A: Personal information of respondent. This part contains the personal information that aims to help the researchers find and understand the background of research subjects. The section contains seven items intended to obtain information relating gender, nationality, age, occupation, income, tenure, and ethnicity

Section B: Understanding of law enforcement of waste management effort in reducing flood risk issues. This part consist of 11 items to assess aspect of understanding on law enforcement of waste management effort in reducing flood risk issues namely:

1. Waste threat is a serious problem in your home.

2. The waste problem is also threat in Palembang City.

3. Waste was burdening the community.

4. Problem such as flood was burdening community.

5. Trash can available in your house.

6. The availability of temporary waste station at your neighborhood is enough.

7. The problem of Law enforcement of waste management is due to uncontrolled waste disposal.

8. Flood risk cannot be avoided.

33 Maruf, "Law and Policy in Addressing Marine Plastic Litter: Indonesia Response and Recent Development”, Journal of Indonesian Legal Studies, 2019, p. 177. 
9. The problem arises because weak of law enforcement of waste management.

10. The problem arises due to dispose waste carelessly.

11. This problem arises because there is no cooperation among society.

All respondents were provided with five options based on the following Likert scale: 1 . Strongly Disagree. 2. Disagree. 3. Not Sure. 4. Agree. 5. Strongly Agree.

The study population is of Palembang City community. In order to represent the entire Palembang City community, the study involved only near to five hundred respondents in seeking views on aspects of awareness and political cooperation in addressing law enforcement waste management efforts reducing flood risk in Palembang City. The study involved 475 respondents randomly selected from several sub district in Palembang City, namely Ilir Barat I, Ilir Barat 2, Kertapati, Ilir Timur I, and Seberang Ulu I. The samples were made up all walks of life that represent the population. By disregarding data that cannot be analyzed, the sample was about 475 .

The data obtained from questionnaires were processed using Statistical Package for the Social Science (SPSS) software. Descriptive statistics were used for percentage and frequencies. Descriptive analysis is a comprehensive technical descriptive of the status of the survey which aims to provide an initial overview of demographic profile. In analyzing the data, researchers are concerned with the complete answers of respondents. Thus, incomplete questionnaires would be misleading and will be deducted from the analysis.

\section{Result}

Palembang is a city with a high amount of waste production each the day. Palembang city is estimated to produce approximately $0.7 \mathrm{~kg}$ of waste a day per person. ${ }^{34}$ If multiplied by the number of people who almost reached figure of 1.7 million inhabitants, the city of Palem-

34 Indar, Pengolahan Sampah Kota Palembang (Garbage Management in Palembang City), September 20 2019. (Azhar, Interviewer). 
bang produces around 1200 tons of waste in a day. Palembang City Government has one Final Disposal Site (TPA) waste located in the Sukawinatan area. TPA capacity there is actually no longer sufficient compared to the amount of production garbage produced every day by residents of Palembang. Processing garbage is also considered to be very inadequate with the number of excavators there are still three and only those who work in that area totaling 60 people to process and regulate the condition of the final disposal site such waste. ${ }^{35}$ On a temporary basis the Department of Environmental and Cleanliness of Palembang City that the capacity of this TPA is only will be able to accommodate waste for the next 20 years with a treatment system landfill control bins. Waste treatment system with this method is by compact the rubbish collected at the final disposal site. Rubbish it is then only covered with soil so that the smell and the environmental impactothers have no impact on the surrounding environment. ${ }^{36}$

The facts show that the number and capacity of polling stations in Palembang City have not sufficient to accommodate waste production that can reach 1200 tons per day. For example Sukawinatan TPA which has an area of 25 ha now only set aside 3 ha to accommodate waste production with a pile of garbage reaching 15 meters so that the diverted TPA Karya Jaya is still hampered by access infrastructure affecting the operation of the landfill which is predicted to start operating in 2021. ${ }^{37}$ Another problem faced by the Palembang City is a temporary Trash that often experiences problems and rejection by the community because of the location of the TPS that is close to residence of citizens. TPS has a bad environmental impact on the process the life of the surrounding community such as the spread of smells and flies and possibilities cause disease is also left continuously.

Recycling has actually begun to be carried out by the government through a program of making plastic pellets and compost. This Recycling had done using the garbage bank method. Data shows 
there are 28 garbage banks spread throughout areas in Palembang city. This is appropriate with the policy of the Mayor of Palembang that requires every area should have garbage bank.

Department of Environmental and Cleanliness of Palembang City, mention that there are some major problems encountered in processing garbage in Palembang City. The first problem is people's ignorance to be fostered and invited to move together to empower waste through banks rubbish. The second problem is the mindset of the community that combines waste as the same entity, each form, even though each waste has its own classification and must be separated. The government has tried to do it continuously socialization related to garbage banks to the district level in the city of Palembang. However, the people's mindset about waste is indeed quite difficult to change. Based on the findings in the field that the efforts made by Department of Environmental and Cleanliness of Palembang City in the form of a garbage bank program are not going well. This is due to the lack of socialization, guidance and assistance from related agencies. Thus it is difficult to get maximum results. Besides doing recycling efforts using the garbage bank method, the government is seeking foreign investors to turn waste into fuel. This matter is being explored by the city government so that waste problems can be a source new income for the region. Converting trash to diesel requires technology sophisticated and inviting foreign investors is one way out presented to reduce this problem. ${ }^{38}$

The fleet is owned by Department of Environmental and Cleanliness of Palembang City has 102 fleets. However, the number of fleets owned has not reached an ideal as many as 160 fleets to accommodate the amount of waste production. For example 40 trucks are used to transport 300 tons of garbage from the market every day and more for the household area. With this condition, in the draft APBD Palembang City in 2019, DLHK submitted as many as 20 containers and 9 dumtruck and 2 new bulldozers. Apart from that the janitor is only owned as many as 580 people from the total needs needed as 
many as 2000 officers. ${ }^{39}$

So far the street sweepers that are scattered in the city of Palembang numbered 580 with a radius of 500 meters spread across the entire 1.3 million meter road section that must be swept by officers. ${ }^{40}$ However, this condition results in lack the required street sweepers are 2144 officers with a radius of 500 meters. Most of the garbage production in Palembang is more than $20 \%$ sourced from Seberang Ulu both from traditional markets, shops and homes. This happened because Seberang Ulu did not have adequate TPS. In addition, the behavior of people who do not have awareness and concern for garbage makes the problem of garbage in Seberang Ulu difficult to overcome. ${ }^{41}$ This is also based on the results from the field data illustrated in Table 1. One of the causes is TPS which are spread unevenly, less in number, and TPS damage was done by local residents.

Table 1

\begin{tabular}{ccc}
\hline & Percent & Cumulative Percent \\
\hline Strongly disagree & $3 \%$ & $3,0 \%$ \\
\hline Disagree & $10,4 \%$ & $13,4 \%$ \\
\hline Doubt & $13,1 \%$ & $26,5 \%$ \\
\hline Agree & $44,4 \%$ & $70,9 \%$ \\
\hline Strongly agree & $29,1 \%$ & $100 \%$ \\
\hline
\end{tabular}

Source : Data processed by researchers

In table 1 above, the results in the field of responses disagree as much $3.0 \%$. Then the respondent's response was $10.4 \%$ on Disagree. On the percentage of doubtful as much as $13.1 \%$ of respondents responded about its importance Throw garbage in its place. This means that there are approximately $26.5 \%$ who do not agree and hesitate to dispose of trash in its place. This is quite prominent so there is still a lot of rubbish on the streets that ultimately leads to drainage and river that can cause the risk of flooding. A total of $44.4 \%$ agreed to the respondents. Then the response strongly agrees to a total of $29.1 \%$

39 Ibid.

40 Ibid.

41 Ibid. 
respondent. From the description above it can be concluded that the highest percentage is at Agree responses regarding the importance of throwing trash in its place.

While answering questions about respondents' awareness about "Did the respondent ever throw up the river?" From the findings of the data regarding the above questions can be seen in Table 2 as follows:

Table 2

\begin{tabular}{ccc}
\hline & Percent & Cumulative Percent \\
\hline Strongly disagree & $0,4 \%$ & $0,4 \%$ \\
\hline Disagree & $0,7 \%$ & $1,1 \%$ \\
\hline Doubt & $22,8 \%$ & $23,9 \%$ \\
\hline Agree & $49,6 \%$ & $73,5 \%$ \\
\hline Strongly agree & $26,5 \%$ & $100 \%$ \\
\hline
\end{tabular}

Source : Data processed by researchers

At the percentage of data, as much as $0.4 \%$ strongly disagree with the response respondent regarding question about Did the respondent ever throw up the river? Then $0.7 \%$ of respondents were Respond Disagree. Furthermore, findings can be seen at $22.8 \%$ regarding Doubtful responses of respondents. $49.6 \%$ of respondents agreed awareness of respondents going to throw garbage into the river in Palembang city. And $26.5 \%$ of respondents strongly agree. Based on the table description above it can be concluded that as many as $76.1 \%$ have ever thrown garbage in the river. The highest percentage is in the Agree response to throwing garbage in the river. This is one of the contributors to the risk of flooding in the city of Palembang.

Table 3

\begin{tabular}{ccc}
\hline & Percent & Cumulative Percent \\
\hline Strongly disagree & $4,9 \%$ & $4,9 \%$ \\
\hline Disagree & $16,0 \%$ & $20,9 \%$ \\
\hline Doubt & $32,8 \%$ & $53,7 \%$ \\
\hline Agree & $32,8 \%$ & $86,6 \%$ \\
\hline Strongly agree & $13.4 \%$ & $100 \%$ \\
\hline
\end{tabular}

Source : Data processed by researchers 
Questions about the participation of respondents in cleaning culverts and or other water flow around the environment. From these findings can be at see in Table 3.

As many as $4.9 \%$ responded answered Strongly Disagree. Whereas $16.0 \%$ answered disagree, the doubtful answer correspondent answered as much as $32.8 \%$. For agreed answers, respondents answered $32.8 \%$, and for answers strongly agree that respondents answered as much as $13.4 \%$, from the data it can be concluded that almost half of the total responsiveness ever did the sewer cleaning culvert and river flow around the environment. While $50 \%$ of respondents did not have done cleaning the mutual cooperation and river flow around its environment. This means that public awareness of the environment has not yet been fully as expected.

Questions about people's understanding of discarding actions garbage and its effects which can cause flooding. From the findings in the field can be seen in Table 4 as follows:

Table 4

\begin{tabular}{ccc}
\hline & Percent & Cumulative Percent \\
\hline Strongly disagree & $1,9 \%$ & $1,9 \%$ \\
\hline Disagree & $5,6 \%$ & $7,5 \%$ \\
\hline Doubt & $6,7 \%$ & $14,2 \%$ \\
\hline Agree & $30,2 \%$ & $44,4 \%$ \\
\hline Strongly agree & $55,6 \%$ & $100 \%$ \\
\hline
\end{tabular}

Source : Data processed by researchers

In table 4 above it can be explained that $1.9 \%$ strongly disagree. While $5.6 \%$ answered disagree, the correspondent's doubtful answers answered as much as $6.7 \%$. For answers agreed there are respondents answered as much $30.2 \%$, and for answers strongly agree respondents responded as much as $56.6 \%$, from the data can be concluded that the majority of respondents are sure two-thirds of the overall response has a good understanding of the disposal pattern garbage and its impact on the environment that causes flooding. 


\section{E. Discussion}

According to Article 1 Paragraph 1 of Law No. 18 of 2008 concerning Waste Management, supports waste as human daily activities and / or natural processes that are formed solid. Meanwhile, according to Nasih, waste is the residue of a business or activity (human) with a solid balance (both in the form of organic and inorganic substances which can be decomposed and also not decomposed) and is considered no longer useful (adjusted for the environment). Supported waste management, transportation, regulation, recycling, or disposal of waste materials. This sentence usually discusses waste generated from human activities, and is usually managed to reduce its impact on health, the environment, or beauty. Waste management is also carried out to restore natural resources. ${ }^{42}$

Waste management can involve solid, liquid, gas, or radioactive substances with methods and special expertise for each type of substance. Waste management practices differ between developed and developing countries, also different between urban and rural areas, as well as between residential and industrial areas. ${ }^{43}$ Management of non-hazardous waste from settlements and institutions in metropolitan areas is usually the responsibility of local governments, while for garbage from commercial and industrial areas is usually handled by waste processing companies. ${ }^{44}$

Whereas Article 1 Paragraph 5 of the aforementioned law and Article 1 Paragraph 16 of Palembang City Regulation No.3 of 2015 concerning Management of Household Waste and Similar Household Waste, referred to as waste management, is a systematic, comprehensive, and sustainable activity including reduction and handling rubbish. Waste management is carried out aimed at improving pub-

42 W. Y, Nasih, Pengolahan Sampah yang Ramah Lingkungan di Sekolah (Enviromental-Friendly Garbage Management in School), Yogyakarta, 2010.

43 P. H. Brunner \& J. Fellner, "Seting Priorities for Waste Management Strategies in Developing Countries”, Waste Management \& Research, 25(3), 2007, p. 234.

44 P. Schübeler, J. Christen, \& K. Wehrle, Conceptual Framework for Municipal Solid Waste Management in Low-income Countries (Vol. 9), St. Gallen: SKAT (Swiss Center for Development Cooperation), 1996. 
lic health and environmental quality and making waste a resource. According to Article 2 Paragraph 1 of Law No. 18 of 2008 managed waste consists of:

a) household waste;

b) household waste; and

c) specific garbage

According to Article 2 Paragraph 2 that household waste is waste originating from daily activities in the household, excluding feces and rubbish Specific. Garbage is a type of household waste originating from commercial areas, industrial areas, special areas, social facilities, public facilities, and / or other facilities (Article 2 Paragraph 3). While Article 2 Paragraph 4 that specific waste covers:

a) waste containing hazardous and toxic materials;

b) waste containing hazardous and toxic material waste;

c) garbage arising from disasters;

d) building debris;

e) solid waste which cannot be treated technologically; and / or

f) garbage that arises not periodically

In terms of waste management that the Government and regional government tasked with ensuring the implementation of good and insightful waste management environment in accordance with the objectives of Article 5 of Law No.18 of 2008 concerning Waste Management (Law No 18/2008). Furthermore, it can be seen that the one doing the waste management is the local government, including planning activities, implementation, management and cooperation and partnerships. This is regulated in the Rules Minister of Home Affairs Number 33 of 2010 concerning Management Guidelines Trash ("Permendagri No.33 / 2010"). Chapter VI on Organizing Waste Management Part One and Part Two of Law No.18 of 2008 Broadly speaking, waste management activities consist of:

a) Management of Household Waste and Household Trash

b) Specific Waste Management.

Based on Article 19 of Law 18/2008 it is said that the management of household waste ladder and household type of solid waste such as: 
a) waste reduction; and

b) garbage handling.

Furthermore, what is meant by waste reduction includes activities according to Article 20 paragraph (1) of Law 18/2008:

a) restriction on waste generation;

b) waste recycling; and / or

c) reuse of waste.

Then for the handling of waste regulated in Article 22 paragraph

(1) of Law 18/2008 includes activities:

a) sorting in the form of grouping and separation of waste according to type, amount and / or nature of waste;

b) collection in the form of collection and removal of waste from the sourcerubbish to a temporary shelter or waste treatment plantintegrated;

c) transportation in the form of carrying garbage from sources and / or froma temporary garbage shelter or from a waste treatment plantintegrated into the final processing site;

d) processing in the form of changing the characteristics, composition, and amount of waste;and / or

e) final processing of waste in the form of waste returns and / or residual yieldprevious processing to the environment safely.

Whereas Article 23 jo. Article 1 number 12 of Management $18 / 2008$ Law Specific waste is the responsibility of the Government (in this case the President as Central Government) and governed by government regulations. Related to this waste management, the central government and regional governments are required finance the implementation of waste management (Article 24 paragraph (1) of the Law 18/2008). This funding comes from the state budget as well as regional income and expenditure budget (Article 24 paragraph (2) of Law 18/2008). In carrying out waste management, the local government can do cooperation between regional governments (Article 26 paragraph (1) of Law 18/2008). This cooperation can be realized in the form of cooperation and/ or joint venture waste management (Article 26 paragraph (2) of Law 18/2008).

In addition, the regency / city regional government individually 
or together can also partner with business entities in waste management implementation of waste management (Article 27 paragraph (1) of Law 18/2008). The partnership was outlined in the form of an agreement between the district / city regional government and the relevant business entity (Article 27 paragraph (2) of Law 18/2008). Anyone can freely conduct business activities waste management, but must have permission from the regional head in accordance with its authority (Article 17 paragraph (1) of Law 18/2008).

According to Government Regulation 16 of 2018 concerning about Satuan Polisi Pamong Praja or SatPol PP Article 5 Item A) Satuan Polisi Pamong Praja enforces the Regional Regulations andRegional Head Regulation; Item B) Organizing public order; and Item $\mathrm{C}$ ) organizing community protection. In terms of law enforcement waste management is the authority of Satuan Polisi Pamong Praja or SatPol PP. Satuan Polisi Pamong Praja who commonly known as SatPol PP is an institution that is engaged for enforcing regional regulations, maintaining regional order and regional peace. The organization and work procedures of the SatPol PP are determined by local regulations. Satpol PP is located under the provincial government to the city / regency government.

Palembang City is an administrative area that has a SatPol PP that functions as law enforcement against local regulations. One of the regulations which is the responsibility of the Palembang City SatPol PP is Perda No. 3 in 2015 related to household waste. Oversight and law enforcement regarding regency policy. This is the responsibility of the SatPol PP to ensure the City communityPalembang has disposed of its garbage in the right place as a place of disposal rubbish. At present, the SatPol PP in Palembang has around 576 personnel. This condition is still not proportional to operating and escorting the road regulations that are owned by the Palembang city government if correlated withthe total population of almost 1.7 million.

SatPol PP in Palembang city is trying to enforce regional regulations as well as possible, including the enforcement of waste laws that are regulated in local regulations No. 3 of 2015 concerning Waste Management. There are several obstacles faced by the SatPol 
PP in enforcing the Regional Regulation. The main problem is in internal SatPol PP with the number of personnel who are still not proportional to escort and regulate Palembang residents. In the context of scale, comparison of numbers Palembang City SatPol PP officers with Palembang City residents are 1: 3400 which means that one civil service police officer must ensure that the public submits of 3400 local regulations. This condition then inhibited SatPol PP to maximize efforts to enforce regional regulations on waste. Another thing that needs to be note, Palembang City Police SatPol is not only responsible for escorting and ensure that only one law is enforced, but there are many local regulations needs to be guarded and ensured the implementation process in the community. The order of the Palembang City SatPol PP officials interviewed by the researchers had good understanding of Perda No. 3 of 2015 related to waste. In explanation, the informant explained that the SatPol PP had tried to enforce the Perda through these two main actions the first is persuasive action with provide socialization related to the waste regulation to the community and guidance against my head littering. This socialization was carried out through distributing pamphlets and banners to the public and conducting reprimands and direct actions to the perpetrators of littering. ${ }^{45}$

The second action is to conduct supervision through a judicial hearing. Trial This law has a strong and binding legal force by stipulating criminal law for 3 months and a fine of 50 million rupiah. But enforcement the law in the context of the court hearing is still difficult to do because it is needed strong evidence and material to make a claim in a judicial hearing. Besides Therefore, coordination between law enforcement institutions is needed to impose a sentence towards the perpetrators.

This study also tried to collect cross data to the community in order to measure the performance of SatPol PP by asking questions about the respondent had seen an officer who disciplined the waste

45 Rivaldy, Penegakan hukum mengenai sampah di kota Palembang (Law Enforcement on Garbage in Palembang City), September 2019. (Azhar, Interviewer) 
problem. the findings can be seen in Table 5, as follows:

Table 5

\begin{tabular}{ccc}
\hline & Percent & Cumulative Percent \\
\hline Strongly disagree & $5,2 \%$ & $5,2 \%$ \\
\hline Disagree & $12,3 \%$ & $17,5 \%$ \\
\hline Doubt & $36,2 \%$ & $53,7 \%$ \\
\hline Agree & $32,5 \%$ & $86,2 \%$ \\
\hline Strongly agree & $13,8 \%$ & $100 \%$ \\
\hline
\end{tabular}

Source : Data processed by researchers

The table above can be explained that $5.2 \%$ strongly disagree. While $12.3 \%$ answered disagreed, the correspondent's doubtful answers answered as much as $36.2 \%$. For answers agreed there are respondents answered as much $32.5 \%$, and for answers strongly agree respondents responded as much as $13.8 \%$. From The data can be concluded that the respondents are divided into two big groups in almost the same composition, where some have seen officers who enforce waste related laws and some never.

SatPol has monitored the enforcement of waste laws. This is done through patrols which are carried out for 24 hours using a rolling system and toured the city of Palembang. In the morning, the SatPol PP team focused myself to conduct surveillance on the morning market area in the city of Palembang,while the daytime is more focused on the 16 Ilir Palembang which is the heart of Palembang. At night the SatPol PP team conducts surveillance at the Kuto Besak Fortress area and the Ampera Bridge. In the analysis of researchers, patrol what SatPol PP does is not just to focus on the waste regulation, but it does patrols are also carried out to enforce other regional regulations. ${ }^{46}$ This then became the researchers' findings on the ineffectiveness of enforcement of Regional Regulations.

The problem faced by SatPol in the findings of the researcher based on interviews conducted is difficult to find perpetrators waste disposal. In general, the SatPol PP found garbage thrown awayin any place without knowing who the perpetrators of the garbage disposal 46 Ibid. 
are. This problem also correlated with the number of SatPol PP officers who were not yet proportionate to the number of residents of Palembang City. In addition, there is still a lack of places proper garbage disposal is also a problem in the distribution of garbage many in the city of Palembang. Making temporary landfills (TPS) often experience rejection from the community because of its environmental impact very disturbing people's lives, especially the problem of smell and flies as well improper garbage monitoring becomes a supporting variable to see the complexity of the Palembang City waste problem.

In the context of river cleanliness and dreinase rubbish cleanliness, SatPol PP does not yet have a large concern on this issue, only the Mayor of Palembang is currently focusing on promoting mutual cooperation for river cleaning through the involvement of elements the government including SatPol PP and the community. This program is named after the program river normalization that has been realized in the Sekojo river area.

In the Satpol PP Palembang City perspective, the waste problem that occurred at Palembang city is actually donated in almost all Palembang city. It's just that when seen visually, this problem is clearly seen in the Upper section Palembang. This is evidenced by the large amount of garbage that has accumulated in the region Pulau jalan (roadblock in the middle of main road), which is always piled up every day. In addition, the Ulu area of Palembang is the entrance for migrants who pass through land route to enter the city of Palembang. This is very disturbing City Branding Palembang as a city that often gets Adipura. However, Mayor sat it focuses on clearing the area as the initial focus of completion garbage problem. ${ }^{47}$

The problem of waste in the city of Palembang cannot be centralized in only one government institution, coordination between related agencies is needed to overcome this problem. The findings in this research interview mentioned that the revitalization and performance efficiency of the City Department of Environment and 
Cleanliness Palembang is the key to alleviating the problems being faced. Providing adequate waste disposal rooms will make it easier community to be able to orderly in the action of garbage disposal so that the problem this can be solved gradually. Law enforcement related to disposal Waste is needed, but law enforcement will not be effective if the government is unable to provide space or waste disposal areas adequate for the community. With no space / area available proper and adequate waste disposal community continues to dispose of waste in an orderly manner.

\section{F. Conclusion}

From the findings and discussion above, the model of waste management law enforcement in Palembang City involves two agencies under the city government of Palembang. The two agencies responsible for enforcing waste management in Palembang City are Department of Environment and Cleanliness Palembang and Satpol PP. Department of Environment and Cleanliness Palembang is responsible for household waste management, Temporary Disposal Sites, Final Disposal Sites and waste management such as waste recycling, while the Palembang City SatPol PP is tasked with enforcing the law on waste management in the city of Palembang. As law enforcement officers SatPol PP has the duty to ensure that the community throws garbage in its place. The SatPol PP has enforced the Perda on waste with persuasive action, which is socializing the Perda on rubbish to the public as well as fostering the practice of littering. This socialization was carried out through the distribution of pamphlets and banners to the public and to do reprimands and direct coaching actions to the perpetrators of littering at the scene. The second action is to conduct supervision through a judicial hearing. This court session has a strong and binding legal basis. With the threat of criminal punishment for 3 months and a fine of 50 million rupiah. In reality, law enforcement in the context of a judicial hearing is still difficult because of the need for strong evidence and materials to make demands in a judicial hearing. From the field findings that the enforcement of 
waste management carried out by Satpol PP Palembang City has not been maximized.

\section{Bibliography}

\section{Legal Instruments}

Law of the No. 24/2017 on Disaster Countermeasure

\section{Books}

Dellyana, S., Konsep Penegakan Hukum (The Concept of Law Enforcement), Yogyakarta: Liberty, 1988.

Iskandar, Cerminan Buram Penegakan Hukum di Indonesia (Blurred Reflection of Law Enforcement in Indonesia), 2008.

Jambi, R., Teori Penegakan Hukum yang Menjamin Kepastian Hukum (The Theory of Law Enforcement That Ensure Legal Certainty), 2015.

Kodoatie, R. J., \& Sjarief, R., Pengolahan Bencana Terpadu (Integrated Disaster Management), Jakarta: Yarsif Watampone, 2006.

Muladi., Kapita Selekta Sistem Peradilan Pidana (The Capita Selecta of Criminal Justice System), Semarang: Undip, 1995.

Nasih, W. Y., Pengolahan Sampah yang Ramah Lingkungan di Sekolah (The Enviromental-Friendly Management of Garbage in School), Yogyakarta, 2010.

Rahardjo, S., Penegakan Hukum: Suatu Tinjauan Sosiologis (Law Enforcement: A Sociological View), Yogyakarta: Genta Publishing, 2009.

Soekanto, S., Faktor-faktor yang Mempengaruhi Penegakan Hukum (Factors Affecting Law Enforcement), Jakarta: Raja Grafindo Persada, 2004.

\section{Articles/Journals}

Adeleka, I., "Vulnerability assessment of an urban flood in Nigeria: Abeokuta flood 2007", Natural Hazards 56 (1), 2011.

Belladona, M., Analisis faktor lingkungan penyebab banjir Kota Palembang (Analysis on the Enviromental Factors Causing Flooding 
in Palembang City), 2005. Retrieved Mei 2020, from www.etd. repository.ugm.ac.id: http://etd.repository.ugm.ac.id/home/ detail_pencarian/26680

Birkmann, J., Garschagen, M., Krass, F., \& Quang, N., "Adaptive urban governance: new challenges for the second generation of urban adaptation strategies to climate change", Sustainability Science, 5(2), 2010.

Bradshaw, C. J., Sodhi, N. S., PEH, K. S. H., \& Brook, B. W., "Global evidence that deforestation amplifies flood risk and severity in the developing world", Global Change Biology, 13(11), 2007.

Boyle, A., "Human rights and the environment: where next?", European Journal of International Law, 23(3), 2012.

Brunner, P. H., \& Fellner, J., "Setting priorities for waste management strategies in developing countries", Waste Management \& Research, 25(3), 2007.

Elgizawy, S. M., El-Haggar, S. M., \& Nassar, K., "Approaching sustainability of construction and demolition waste using zero waste concept". Low carbon economy, 7(1), 2016.

Holdren, J. P., \& Ehrlich, P. R., "Human Population and the Global Environment: Population growth, rising per capita material consumption, and disruptive technologies have made civilization a global ecological force". American scientist, 62(3), 1974.

IFRC. World Disaster Report 2010: Focus On Urban Risk. Geneva: IFRC, 2010.

Jha, B. A., \& Lamond, J., Cities and flooding: a guide to integrated urban flood risk management for the 21st century. W. World Bank Publications, 2012.

Maruf, "Law and policy in addressing marine plastic litter: Indonesia Response and Recent Development", Journal of Indonesian Legal Studies , 2019.

Nicholls, R. J., "Coastal flooding and wetland loss in the 21st century: changes under the SRES climate and socio-economic scenarios", Global Environmental Change, 14(1), 2004.

Priyono, F. J., "Law Enforcement of Electrical and Electronic waste smuggling in Batam, Indonesia", Diponegoro Law Review, 2017. 
Razafindarabe, B., Kada, R., Arima, M., \& Inoue, S., "Analyzing flood risk and related impacts to urban communities in central Vietnam", Mitigation and Adaptation Strategies for Global Change, 2012.

ScanlonB.R, Jolly I, Sophocleous M, \&Zhang L., "Global Impact of Conversions from natural to agricultural ecosystems on water resources: Quantity versus quality", Water resources research 43 (3), 2007.

Schübeler, P., Christen, J., \& Wehrle, K., Conceptual framework for municipal solid waste management in low-income countries (Vol. 9), St. Gallen: SKAT (Swiss Center for Development Cooperation), 1996.

Tingsanchali, T., "Urban Flood Disaster Management". Procedia Engineering , 2012.

Walhi, Catatan Akhir Tahun 2019 : Tinjauang Lingkungan Hidup Sumatera Selatan, 2019. Retrieved Mei 2020, from www.walhi.or.id: https:/ / www.walhi.or.id/wp-content/ uploads / Laporan $\% 20$ Tahunan/ catahu.pdf

\section{Interview}

Rivaldy. Penegakan hukum mengenai sampah di kota Palembang (Law Enforcement on Garbage in Palembang City), September 2019. (Azhar, Interviewer)

Indar, Pengolahan Sampah Kota Palembang (Garbage Management in Palembang City), September 20 2019. (Azhar, Interviewer)

\section{Others}

Garner, B. A., Black Law Dictionary. St. Paul: West Publishing, 1999. KBBI, KBBI (Indonesian Dictionary). Jakarta, 1998. 